\title{
Ureter Schwannoma
}

National Cancer Institute

\section{Source}

National Cancer Institute. Ureter Schwannoma. NCI Thesaurus. Code C6162.

A benign nerve sheath tumor composed of Schwann cells, occurring in the ureter. 